\title{
The Implementation of School Literacy in Primary School
}

\author{
Kurniati Syamsu \\ Universitas Muhammadiyah Sidoarjo \\ Sidoarjo, Indonesia \\ kurniati_syamsu@yahoo.com
}

\begin{abstract}
School Literacy (Gerakan Literasi Sekolah$G L S$ ) proclaimed by The Ministry of Education and Culture (Kementrian Pendidikan dan Kebudayaan-Kemendikbud) to strengthen the movement of moral character as stated in the Minister of Education and Culture Regulation No. 23 of 2015 received a response from elementary school toward the activities of character education implementation in the form of attitude. Primary schools are aware that the students' reading interest is very low as evidenced by the daily re-examination of less Indonesian subjects. This research includes qualitative descriptive research. The data collection techniques used interviews, observations and documents. The data then analyzed through the process of data selection, withdrawal conclusions. The results of the study show that the first stage of the GLS (habituation) conducted by primary schools has run well by paying attention to the activities set by Kemendikbud described in ten indicators of GLS success.
\end{abstract} school;

Keywords-school literacy; cultural literacy; primary

\section{INTRODUCTION}

Basically, the school literacy conducted in elementary school is a kind of manifestation of the activity proclaimed by the Ministry of Education and Culture No. 23 of 2015. The Schools respond to the literacy program of the school seriously. This is because the fact says that the reading interest in primary school students is still low. This is evidenced by the low repetition of semester students, especially in Indonesian language subjects.

The results of a survey conducted by the Program for Economic Cooperation Assessment (PISA) under the Organization Economic Cooperation and Development (OECD) in 2012 were quite surprising. The institutions that mapped the math, reading, and science capabilities scored Indonesia at the lowest position of 65 countries in the world for reading interest.

In the same year, UNESCO also pointed out the fact that Indonesia has an index reading of 0.001 . It means that out of 1000 people in Indonesia, there is only one person who has a will to read (Ampul, 2016). The results of these studies and surveys have not been added to the results of other studies such as the Human Development Index (HDI) and Trends in International Mathematics and Science Study (TIMSS) which indirectly can also support findings on the low level of literacy in Indonesia.
The information era is identical to the literacy era that describes the ability to interact, communicate, and even actualize which is not enough to be expressed verbally, but also written. Literacy is very important for students because literacy skill will affect their success learning and their life. Good literacy skill will assist the students in understanding oral, written, or visual/visual texts. Therefore the development of student's literacy in learning is always conducted in an integrated manner between listening, speaking, reading and writing activities. That's because these four skills have a very close relationship, although each has certain characteristics.

But in fact, the students' condition in doing literacy is still apprehensive. Taufik Ismail states that our society in general is a mythical reading and paralytic writing. Therefore teachers should be good at implementing strategies that can develop student literacy in primary school learning.

Simply, literacy means the ability to read, write or literate. In the present context, literacy has a very broad meaning. Literacy can mean technological literacy, politics, critical thinking, and sensitive to the environment. Furthermore, one can be said to be literate if one can understand something by reading and doing something based on the reading comprehension.

This fact is a challenge for the next generation of the nation, because the findings about the early ability of reading children can be a potential to revive the culture of Indonesian children's literacy. Departing from this, the primary school then implemented the School Literacy Program.

This study aims to describe the literacy activities in primary schools. This research is limited to GLS's first program of habituation. While the advantages of this research is to add insight about the implementation model of School Literacy activities.

\section{METHOD}

This research uses descriptive qualitative approach. This approach is used with the assumption that qualitative research will get a naturalistic object, so it can reveal the problem in detail and depth. This research was conducted at SD Muhammadiyah 1 Sidoarjo. The subjects of this study were principals and teachers. Techniques of data collecting in this research are interview, observation, and 
documentation. Data validity is done by triangulation technique by checking the data to the same source with different techniques. In this study comparing interview methods, observation and documentation. The data are analyzed through the process of data selection, collection of data withdrawal conclusions.

\section{THEORETICAL REVIEW}

\section{A. Understanding School Literacy Movement}

Literacy comes from the Latin language littera which means involving mastery of the writing systems and accompanying conventions [1]. According to the Indonesian Dictionary, literacy is the ability to write and read [2]. Another opinion states literacy is interpreted literacy or literacy [3]. In the context of GLS, literacy is interpreted as the ability to access, understand, and use things intelligently through various activities, including reading, viewing, listening, writing, and or speaking.

The School Literacy activities is a comprehensive effort to make schools a learning organization whose citizens are literate throughout life through public engagement [5].

The people involved in the GLS include all the school communities (students, teachers, principals, education personnel, school committees, school supervisors, parents), academics, publishers, mass media, society and stakeholders under the coordination of the Directorate General of Primary Education Ministry of Education and Culture. The School Literacy is expected to encourage the schools communities, stakeholders, and communities to jointly implement, and make this activity an important activity in life [6].

There are two purposes of GLS: general and special purpose. The general purpose of the GLS is to nurture students' morality through the culture of the school literacy ecosystem embodied in the School Literacy program to become lifelong learners [7].

While the specific purpose of GLS is a) Developing a culture of literacy in schools, b) Improving the capacity of citizens and the school environment for literacy, c) Make the school as a fun and child-friendly learning park so that the school community can manage knowledge. d) Maintaining the continuity of learning by presenting a variety of reading books and accommodating various reading strategies [8].

The GLS in Primary School is implemented gradually by considering the readiness of each school. This readiness includes the readiness of the school's physical capacity (availability of facilities, literacy infrastructure), the readiness of learners, teachers, parents, and other community components), and the readiness of other support systems (public participation, institutional support and policy tools which is relevant) [9].

\section{B. Stages and Steps of GLS}

Stages of GLS implementation is divided into three: 1). Habituation, growing the reading interest through the activities of 15 minutes to read (Permendikbud No. 23 of 2015) 2). Development in the form of literacy improvement through enrichment activities 3). Lessons are increased literacy skills in all subjects: using enrichment books and reading strategies in all subjects [10].

In the early stages, this program is still struggling in the very first stage, habituation. Habituation stage provides some steps of activities performed in the GLS: a) Read 15 minutes before the lesson begins b) Organize rich media and literacy facilities c) Create a text-rich environment d) Select reading books in SD e) Public engagement [11] .

The first step, the reading activity is done 15 minutes before the lesson begins with the technique of reading aloud and silent reading. Reading aloud is done by the Master / librarian / headmaster / volunteer to read out books / other reading materials loudly. The aims are: a) Motivate learners to read. b) Make learners can read and love to read. c) Provide a pleasant reading experience. d) Building communication between teachers and learners. e) The teacher / librarian / principal becomes the model of reading.

Sustained silent reading is a 15 minute reading activity given to learners without interruption. The teacher creates a calm, comfortable atmosphere, so that learners can concentrate on the book they read. The goal is to foster reading habits in learners [12].

The second rare is to organize facilities and infrastructure. The literacy facilities include school library, classroom reading corner, and reading area. The library serves as a learning center at school. The development and arrangement of libraries is an important part of the school literacy implementation and also knowledge-based management. Well-managed libraries can increase the reading interest of the elementary school and make them lifelong learners. The school libraries should ideally play a role in coordinating the management of class corner reading, reading areas, and other literacy infrastructures in primary schools.

The third step is to create a text-rich environment. To foster a culture of literacy in the school environment, classrooms need to be enriched with text-rich materials. Examples of text-rich materials are: 1). works of learners in the form of writing, drawing, or graphics; 2). lesson-related posters, book posters, reading campaign posters, and other campaign posters aimed at fostering the love of knowledge and character; 3). word wall; 4). label the names of learners on their belongings stored in the classroom (if any); 5). daily schedule, division of class task groups; 6). letters, recipes, coupons, clippings, photos of learners' activities; 7). Label names on every object in the classroom; 8). computers and / or other electronic devices that support literacy activities; 9). books and other sources of information (newspapers, magazines, newsletters); 10). bulletin boards; 11). posters and alphabet toys; 12) story cassettes, DVDs, and digital / electronic materials that support literacy activities, 13). Creating and writing tools such as stationery, color tools, drawing tools, drawing paper, waste paper, foam, construction paper, letters, letter paper, envelopes, old newspapers, cover papers, etc .; 14). dolls, blocks, costumes, and other educational games to use in role playing (being a doctor or cook writing recipes, or restaurant waitress writing order lists); 15). welcome greeting and motivating words at 
the door of the classroom, the aisle of the Elementary School, and other easily visible places; and 16). all materials and tools should be stored in a place that the learners can easily reach and need to be grouped by function (drawing tools kept separate from toys, role playing tools, etc.); learners need to know where they can find the materials they need [13].

The fourth step is to choose the reading text-book in the elemntary school. This step is divided into two, special lower and upper classes. The lower classes are grade 1 to 3 while the upper classes are grade 4 to 6 . There are differences in characters and abilities between classes, so the selection of reading text-books should pay attention on these differences.

The fifth step is public engagement. Public engagement is required to: 1). The development of literacy facilities requires adequate resources. The participation of school committees, parents, alumni, and the business and industry can help maintain and develop the school facilities so that students' literacy achievements can be improved. 2). With the involvement of more and more parties, learners can learn from different models of literacy examples. 3). School ecosystems are open and schools are getting better trust from parents and other elements of society. 4). Schools learn to manage support from various parties so that school accountability will also increase [14].

\section{GLS Success Indicators}

There are 10 indicators of successful GLS implementation for institutions. These 10 indicators are measured by checking the no and yes columns. The ten indicators are: 1). An activity of 15 minutes reading: a. Reading aloud. b. Silent reading ; 2). Activity 15 minutes Reading is done daily (at the beginning, middle, or towards the end of the lesson). ; 3). Books read to or read by learners are recorded by the author's title and name in the diary. 4). Teachers, principals, and other education personnel engage in 15-minute activities by reading books or reading in the heart; 5). There is a school library or a special room for storing non-lesson books. 6). There is a Reading Corner in each class with a collection of non-textbooks; 7). There are posters reading campaigns in the classroom, corridors, and other areas of the school; 8). There is a text- rich material in each class; 9). School gardens, cafeterias, and school heath unit become the rich environment of literacy. There are posters on healthy lifestyle, hygiene, and beauty in school gardens, cafeterias and school heath unit. Food in the school canteen is clean and healthy; 10). Schools seek to involve the public (parents, alumni, and other community elements) to develop school literacy activities.

\section{FINDING AND DISCUSSION}

The school literacy (GLS) activities has been implemented in this elementary school, precisely in 2015 where GLS is echoed. However, when we look back the chronology literacy in primary school, it has been implemented. This was stated by the principal of Primary School Ms. Enik. Some of the literacy programs in question are: 1) Primary schools have familiarized the reading for their students before the lesson begins. Both reading the
Qur'an and other texts. 2) The procurement of reading books in elementary school libraries is always increasing from year to year. 3) the class is designed to be rich in science with many displays and student work. 4) Involvement of guardians in improving the quality of schools, including increased interest in reading students in school. 5) own printing of literacy materials with the purchase of special printers.

In this discussion, researcher breaks down the five steps of GLS. The first step, reading activities 15 minutes before learning. In the observations, this stage has been done both in the lower class (I-III) and in the upper class (IV-VI). In the lower classes, the teachers implemented reading aloud in front of the class. One of the teachers we observed was the first grade teacher from Umar Bin Khattab class. Sri Rahayu. The teacher read with good expression, gestures and intonation so that the students focus on listening to the teacher's reading. Sri Rahayu also stopped reading if she saw a busy student. This way is used to make other children stay and focus to listen to the reading. Rahayu also provides space for students who respond to teacher's readings. Occasionally teachers answer student's questions. The observations were also made in class II of Usman bin Affan with Classroom Master and Class II Ali bin Abi Talib with the Class Master. The same scene is also found in the author of the class.

Each class teacher made a journal that contains some read books. If the text of the textbook is long, the teacher would read it in the following day. This often makes students curious about the rest of stories the teacher read.

In the upper class, 15 minutes reading is treated with two techniques, reading aloud and silent reading. The researcher observed in class IV of Abu Bakar. The students were asked to read silently. Before reading, the teacher invited the students to choose the available reading books in the classroom. The nuance was silent when the students read. At the end of the silent reading, the teacher gave the opportunity to the student who is pleased to tell forward what he has read. Many students wanted to deliver what they read by holding up their hands. The teacher gave two to three people a day. Each student got the chance to present. This was also applied in other classes. Thie same situation was seen in class V Usman bin Affan and Class VI Umar bin Khattab.

The second step is arranging facilities and infrastructure. The literacy facilities include school library, classroom reading corner, and reading area. The library design in primary schools is quite good. The condition of books and shelves are artistically arranged. Library books have also been classified based on the classes. The library at school is using information management system. The library's reading room uses neat tables and chairs. There are also librarians who are ready to serve visitors.

The reading angle in the classroom is also neat. School regulations require students to return back the read book in the first place. This also appears in other reading areas. The reading books are neatly arranged. 
The books are held with two sources. The first is from RABS and second is from parents. Every year, this school budget to purchase textbooks excluding the school textbooks is around 20 million. Then, for parents, they voluntary participate in procuring books.

The third step is to create a text- rich environment. The classroom observation showed that the classroom is filled with many tidy ornaments. The learner's works include writings, drawings, posters, labels of students' names, daily schedules, classroom assignment groups, computers and LCDs, books and magazines, alphabet toys, VCD stories of prophets, DVDs, and others. Outside the classroom, there are also many posters, welcome greetings and motivating words. All placed in accordance with their respective positions.

The fourth step is choosing the reading material for students. Selecting text-book for students is budgeted by the institution on the proposal from various parties. The proposal is then discussed further by the principal and the GLS team. The funds used are school funds that are budgeted per semester about 20 million rupiah.

Other reading sources come from parents. Special textbooks given by parents must first escape the GLS team's censorship. It aims to filter the inconsistent out book content fitted with the age of the students and the purpose of the literacy movement. In addition, reading materials are also obtained from donations, endowments or other party grants, whether it be books, magazines, VCD / DCD stories of prophets and others.

New reading materials is going to be distributed to library, class and reading corner. The books are cometimes rotated from one class to another to provide refreshment to students.

Special books that have been used or damaged will be replaced with new books. The books are not discarded or resold but are donated to other schools in need.

The fifth step is public engagement. This step has been discussed to in the previous discussion where parents, and others contribute to the procurement of this literacy program. In addition, the form of participation is also done by parents to hold their own literacy materials for students in their homes. Thus the literacy program in addition to running at home is also supported by other parties outside the school, especially parents.

The description of five stages implementation of the School Literacy program showed that the habituation stage provides an idea that the school is serious to succeed the program. In addition, 15 minutes reading activity before the lesson begins, organizing facilities and infrastructure, creating text-rich environment, selecting relevant reading for students and public or stakeholder engagement education at the primary school has been well implemented.

The interviews resulted that the field surveys and documentation done by the authors are then included in the checklist sheet. This stage is intended to find out how successful the implementation of this school's literacy is. This sheet contains ten items of indicator. The indicators are then checked on the basis of the findings. The result of data input can be seen in table I:

TABLE I INDICATORS OF ACHIEVEMENT AT THE HABITUATION STAGE

\begin{tabular}{|c|c|c|c|}
\hline No & Indicator & No & Yes \\
\hline 1. & $\begin{array}{l}\text { An activity of } 15 \text { minutes reading: } \\
\text { a. Reading aloud } \\
\text { b. Silent reading }\end{array}$ & & $\rightarrow$ \\
\hline 2. & $\begin{array}{l}\text { Activity } 15 \text { minutes Reading is done } \\
\text { daily (at the beginning, middle, or } \\
\text { towards the end of the lesson). }\end{array}$ & & $\rightarrow$ \\
\hline 3. & $\begin{array}{l}\text { Books read to or read by learners are } \\
\text { recorded by the author's title and } \\
\text { name in the diary. }\end{array}$ & & $\rightarrow$ \\
\hline 4. & $\begin{array}{l}\text { Teachers, principals, and other } \\
\text { education personnel engage in 15- } \\
\text { minute activities by reading books or } \\
\text { reading in the heart. }\end{array}$ & & $\rightarrow$ \\
\hline 5. & $\begin{array}{l}\text { There is a school library or a special } \\
\text { room for storing non-lesson books. }\end{array}$ & & $\rightarrow$ \\
\hline 6. & $\begin{array}{l}\text { There is a Reading Corner in each } \\
\text { class with a collection of non- } \\
\text { textbooks. }\end{array}$ & & $\rightarrow$ \\
\hline 7. & $\begin{array}{l}\text { There are posters reading campaigns } \\
\text { in the classroom, corridors, and other } \\
\text { areas of the school. }\end{array}$ & & $\rightarrow$ \\
\hline 8. & $\begin{array}{l}\text { There is a text-rich material in each } \\
\text { class }\end{array}$ & & $\rightarrow$ \\
\hline 9. & $\begin{array}{l}\text { School gardens, cafeterias, and } \\
\text { school heath unit become the rich } \\
\text { environment of literacy. There are } \\
\text { posters on healthy lifestyle, hygiene, } \\
\text { and beauty in school gardens, } \\
\text { cafeterias and school heath unit. Food } \\
\text { in the school canteen is clean and } \\
\text { healthy. }\end{array}$ & & $\rightarrow$ \\
\hline 10. & $\begin{array}{l}\text { School seeks to involve the public } \\
\text { (parents, alumni, and other } \\
\text { community elements) to develop } \\
\text { school literacy activities. }\end{array}$ & & $\rightarrow$ \\
\hline
\end{tabular}

Based on the five steps of GLS, habituation stage and the results of checklist in table 1, it can be concluded that the GLS program at this elementary school has been well implemented.

\section{CONCLUSIONS}

Based on the above explanation, the researcher concluded that the School Literacy (GLS) implementation at the habituation stage in elementary school has been well implemented. This is marked by the implementation of five steps of habituation activities include: a) Read 15 minutes before the lesson begins, b) Setting facilities and environment rich in literacy, c) Creating a text-rich 
environment, d) Choosing a text-book in at school, e) Publicinvolvement.

Based on the above conclusions, the researcher suggests that the GLS in primary school needs to be upgraded to the next stage: the second stage of development involves enhancing literacy skills through enrichment activities and the third stage of learning: improving literacy skills in all subjects: using enrichment books and reading strategies in all subjects.

\section{ACKNOWLEDGMENT}

I put on my greatest thanks to Universitas Muhammadiyah Sidoarjo for supporting this research.

\section{REFERENCES}

[1] S. Purwo, Peran gerakan literasi sekolah dalam pembelajaran kreatif-produktif di sekolah dasar, J. Dewantara, vol 3, no. 1, 2017, 87.

[2] https://kbbi.kemdikbud.go.id/entri/literasi diakses tanggal 11 Oktober 2017

[3] Indah Wijaya Antasari, Dukungan orang tua dalam membangun literasi anak, J. Edulib, vol. 6, no. 2, 2016, 138

[4] Dirjen Pendidikan Dasar dan Menengah Kemdikbud, Panduan Gerakan Literasi Sekolah di Sekolah Dasar, Jakarta : Kemdikbud, 2016, 2

[5] Dirjen Pendidikan Dasar dan Menengah Kemdikbud, Panduan Gerakan Literasi Sekolah di Sekolah Dasar, Jakarta : Kemdikbud, 2016, 2

[6] D.R. Sari and S. Suharningsih, Hubungan kualitas penerapan gerakan literasi sekolah dengan kemandirian belajar siswa kelas $\mathrm{x}$ smk negeri 1 sidoarjo, J. Kajian Moral dan Kewarganegaraan, vol. 05 , no. $03,2017,993$

[7] Dirjen Pendidikan Dasar dan Menengah Kemdikbud, Panduan Gerakan Literasi Sekolah di Sekolah Dasar, Jakarta : Kemdikbud, 2016, 2

[8] Dirjen Pendidikan Dasar dan Menengah Kemdikbud, Panduan Gerakan Literasi Sekolah di Sekolah Dasar, Jakarta : Kemdikbud, 2016, 2

[9] Dirjen Pendidikan Dasar dan Menengah Kemdikbud, Panduan Gerakan Literasi Sekolah di Sekolah Dasar, Jakarta : Kemdikbud, 2016, 5-6

[10] Dirjen Pendidikan Dasar dan Menengah Kemdikbud, Panduan Gerakan Literasi Sekolah di Sekolah Dasar, Jakarta : Kemdikbud, 2016, 5-6

[11] Dirjen Pendidikan Dasar dan Menengah Kemdikbud, Panduan Gerakan Literasi Sekolah di Sekolah Dasar, Jakarta : Kemdikbud, 2016, 5-6

[12] Dirjen Pendidikan Dasar dan Menengah Kemdikbud, Panduan Gerakan Literasi Sekolah di Sekolah Dasar, Jakarta : Kemdikbud, 2016, 14

[13] Dirjen Pendidikan Dasar dan Menengah Kemdikbud, Panduan Gerakan Literasi Sekolah di Sekolah Dasar, Jakarta : Kemdikbud, 2016, 18-19

[14] Dirjen Pendidikan Dasar dan Menengah Kemdikbud, Panduan Gerakan Literasi Sekolah di Sekolah Dasar, Jakarta : Kemdikbud, 2016, 22 